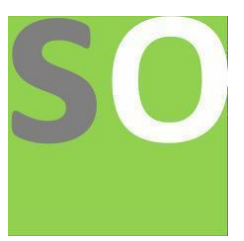

Article title: History Of Epizootics, Epidemics And Evolution Of Coronaviruses

Authors: Olivier Fridolin MAMINIAINA[1], Mirantsoa Suzanne RAZAFINDRAFARA [2]

Affiliations: National Research Center -FOFIFA-Department of Zootechnical, Veterinary and Fish Research (FOFIFA-DRZVP); National Research Center - Malagasy Institute of Veterinary Vaccines (IMVAVET) - Ministry of Higher Education and Scientific Research[1]

Orcid ids: 0000-0003-4149-1267[1]

Contact e-mail: maminiaina.fridolin@gmail.com

License information: This work has been published open access under Creative Commons Attribution License http://creativecommons.org/licenses/by/4.0/, which permits unrestricted use, distribution, and reproduction in any medium, provided the original work is properly cited. Conditions, terms of use and publishing policy can be found at https://www.scienceopen.com/.

Preprint statement: This article is a preprint and has not been peer-reviewed, under consideration and submitted to ScienceOpen Preprints for open peer review.

DOI: 10.14293/S2199-1006.1.SOR-.PPXDXQI.v1

Preprint first posted online: 01 September 2021

Keywords: Coronavirus, bats, tMRCA, viral evolution, animal host, intermediate host, COVID19, COVID 


\title{
HISTORY OF EPIZOOTICS, EPIDEMICS AND EVOLUTION OF CORONAVIRUSES
}

\author{
MAMINIAINA Olivier Fridolin 1-2-3; RAZAFINDRAFARA Mirantsoa Suzanne 1-2 \\ National Research Center - Malagasy Institute of Veterinary Vaccines (IMVAVET) - Ministry of Higher Education and Scientific Research \\ National Research Center -FOFIFA-Department of Zootechnical, Veterinary and Fish Research (FOFIFA-DRZVP) - Ministry of Higher Education \\ and Scientific Research \\ (3) Department of Medical and Veterinary Sciences - Faculty of Medicine - Ministry of Higher Education and Scientific Research
}

\section{ABSTRACT}

As emerging coronaviruses have always become a global human and animal health problem, especially SARS-COV, MERS-CoV and SARS-CoV2 (severe acute respiratory syndrome coronavirus 2), many researchers have focused on the epidemic, virological and clinical characteristics of each coronavirus since the first description of IBV (infectious bronchitis virus) in 1930. Unquestionably, bats act as a natural reservoir for many viruses, including coronaviruses, and have played a crucial epidemiological role in the emergence of many viral diseases in humans or animals via other animals as intermediate hosts. In this review, we will try to situate the different epizootics and epidemics caused by CoV, their reservoir as well as their evolution in relation to the history of human intrusion on their environment. Keywords : Coronavirus, bats, tMRCA; viral evolution, animal host, intermediate host.

\section{INTRODUCTION}

Coronaviruses $(\mathrm{COV})$ are enveloped riboviruses, grouping many viruses that infect several animal species (avian and mammalian), including humans. The term "coronavirus" appeared only in 1968 after the identification of the first human CoV or HCoV (Almeida J. D et al., 1968). The authors compare this type of virus spherical, with rounded excrescences, formed mainly by the spike (S) and protein that resembles a petal with its crowns or "corona" in Latin (Figure-1).
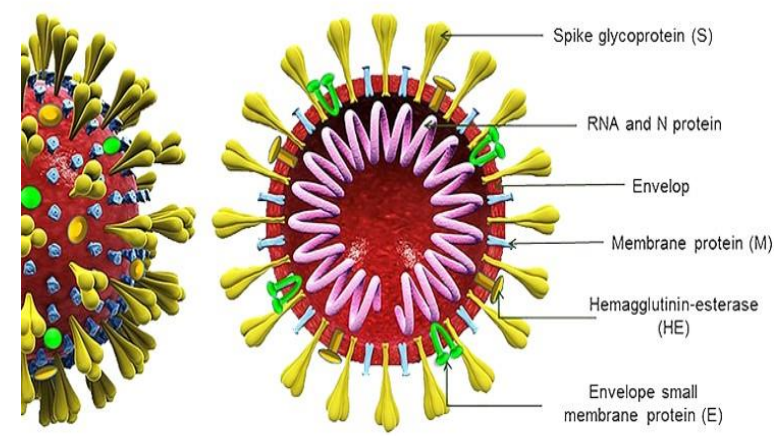

Figure 1: Schematic structure of coronavirus. The virus is an enveloped, non-segmented, positive-sense single-stranded RNA virus. The virion has a nucleocapsid composed of genomic RNA and phosphorylated nucleocapsid $(N)$ protein, which is buried inside phospholipid bilayers and covered by the spike glycoprotein trimmer (S). The membrane (M) protein hemagglutininesterase (HE) and the envelope (E) protein are located among the S proteins in the virus envelope (Jafari A et al., 2020).

Coronavirus genomes $(27-33 \mathrm{~kb})$ encode five large open reading frames (ORFs), including one polyprotein (ORF1a/ORF1ab) in the $5^{\prime}$ and four structural proteins in the $3^{\prime}$, namely spike (S), envelope 
$(\mathrm{E})$, membrane (M), and nucleocapsid (N) proteins (Figure-xx), common to all CoVs (Ashour et al., 2020). Yet, some CoVs possess a fifth structural protein called HE or hemagglutinin-esterase (Fehr and Perlman, 2015). In addition to these structural proteins, CoVs also have accessory proteins that interpose between the structural proteins and vary from each CoV (Figures-2).

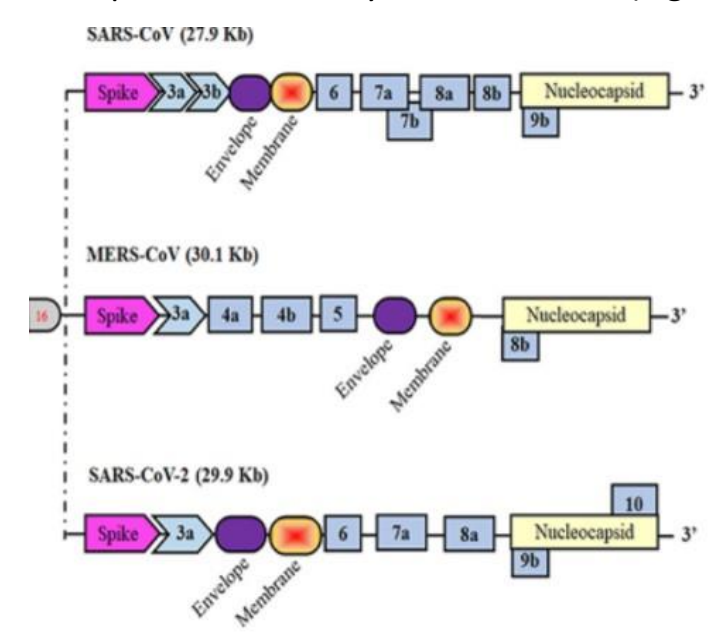

Figure 2: 3' side of the SARS-COV, MERS-COV and SARS-CoV2 genomes showing structural and accessory proteins. Adapted according to Shah's team in 2020 ((Shah et al., 2020).

After the release of the CoV genome into the host cell cytoplasm upon entry marks the beginning of a complex viral gene expression program, which is highly regulated in space and time (V'kovski et al., 2021). Translation of ORF1a and ORF1b from genomic RNA produces two polyproteins, pp1a and pp1ab, respectively. Sixteen nonstructural proteins ( $\mathrm{nsp}$ ) are released upon proteolytic self-cleavage by the two cysteine proteases located in nsp3 for papain-like protease (PLpro) and nsp5 for 3CLpro or chymotrypsin-like protease (Figure-3).

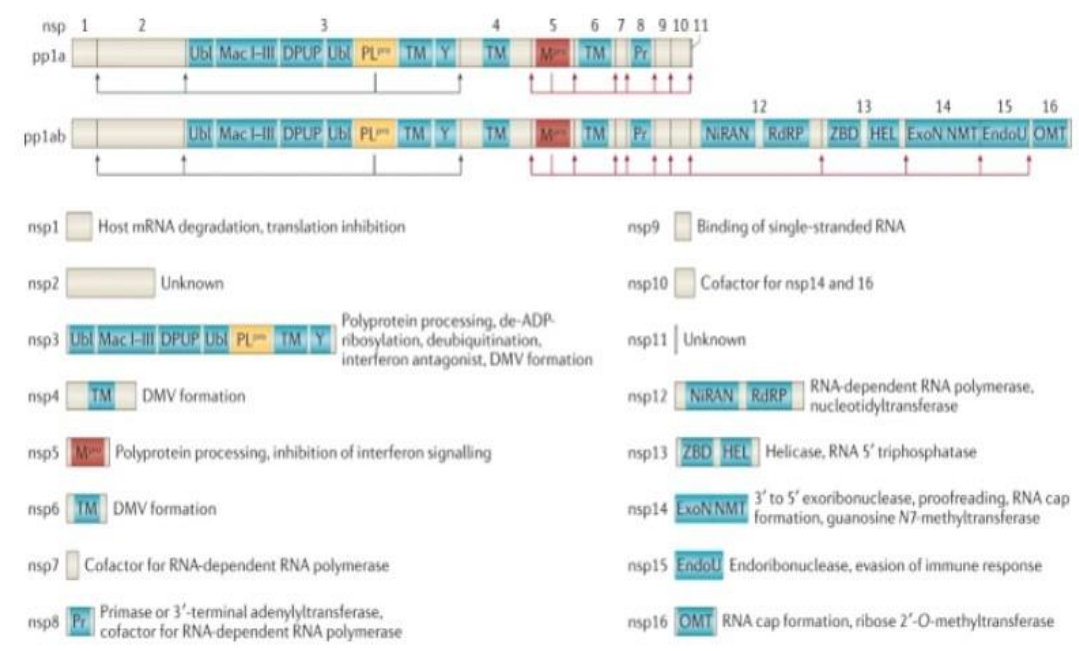

Figure 3: The 16 nsp of SARS-CoV2 according to V'kovski's team in 2021 (V'kovski et al., 2021)

\section{HISTORY OF DISEASES CAUSED BY CORONAVIRUSES}

The first strain of CoV, IBV or Infectious Bronchitis virus (Figure 4), was isolated and identified from infectious bronchitis in chickens in the 1930s (Beaudette and Hudson, 1937). In human medicine, 
research on HCoV did not really start until the identification of the SARS-CoV strain in China in 2003 (Peiris et al., 2004), except for a few authors who reported the first human CoVs HCoV-229E and HCoVO43, which cause common colds in humans (Bradburne, 1970; Hamre and Procknow, 1966). Prior to 2003, the majority of published articles on CoVs refer only to epizootics in livestock (Chasey and Cartwright, 1978; Dea et al., 1981; Doyle and Hutchings, 1946; Tobler and Ackermann, 1996), companion animals (Herrewegh et al., 1998)and mice (Bailey et al., 1949).

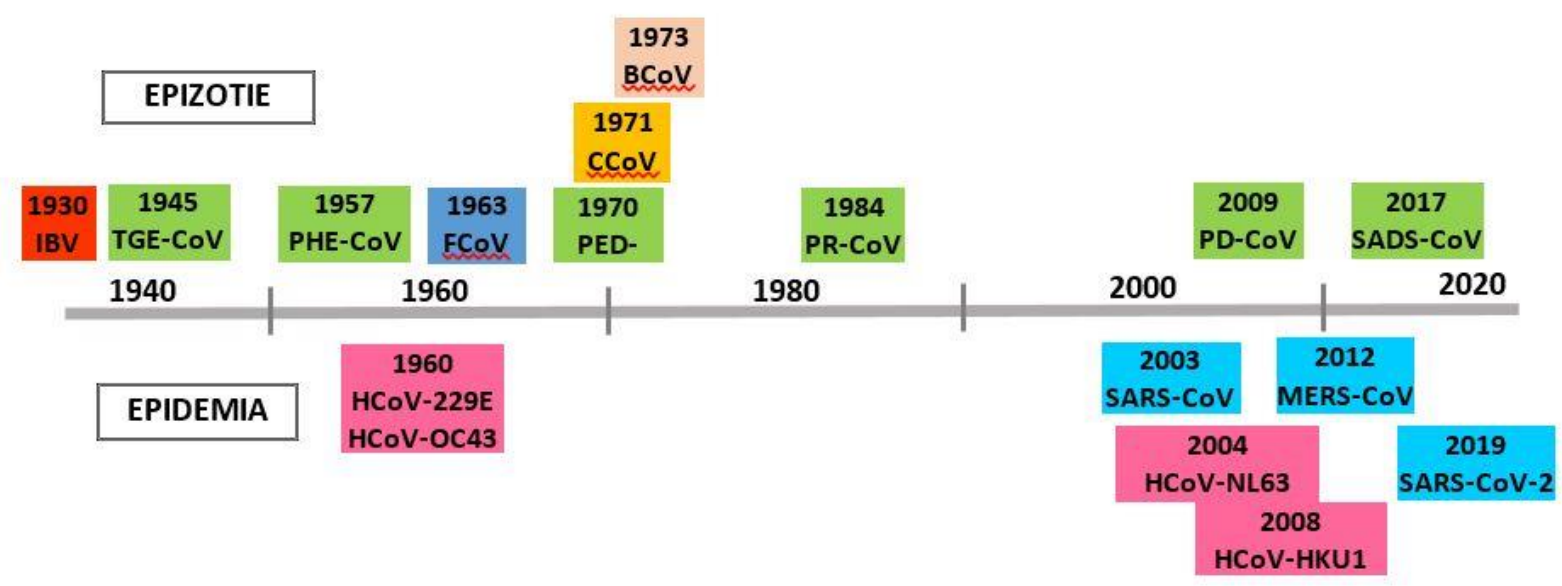

Figure 4: Chronological representation of CoV epizootics and epidemics (Maminiaina OF et al., 2020)

\subsection{CoV diseases in animals}

\subsubsection{Avian infectious bronchitis with coronavirus or CoV-IBV}

The first strain of CoV-IBV, is the agent of avian infectious bronchitis of the genera Gallus gallus domesticus (chickens) and Anser anser (geese) (Beaudette and Hudson, 1937; Cavanagh and Gelb, 2008; Pauly et al., 2019). Infection is characterized by acute respiratory distress, rales, coughing, nephritis, severe clutch drop, deterioration of egg quality, and high mortality in young chicks (Bande et al., 2016).

\subsubsection{Porcine hemagglutinating encephalomyelitis or PHE}

PHE-CoV, the causative agent of neurological and/or digestive diseases in pigs (Mora-Díaz et al., 2019), was one of the first porcine CoVs identified in 1957 and the only neurotropic CoV affecting pigs (MoraDíaz et al., 2019; Roe and Alexander, 1958). Clinical manifestations, including vomiting and emaciation and/or neurological signs, are age-related and are typically reported only in piglets less than 4 weeks of age. Subclinical circulation of PHE-CoV has been reported worldwide (Mora-Díaz et al., 2019). PHE-CoV and some other BetaCoV have a second, shorter spicule, the hemagglutinin-esterase or HE protein (Zeng et al., 2008).

\subsubsection{Porcine Epidemic Diarrhea or PED}

PED-CoV was determined to be the etiologic agent of porcine epidemic diarrhea in the late 1970s (Lee, 2015; Pensaert and de Bouck, 1978). Since then, the disease has been reported in Europe and Asia 
(Antas and Woźniakowski, 2019; Brnić et al., 2019; Hanke et al., 2017; Song et al., 2015). PED-CoV causes acute diarrhea, vomiting, dehydration, high mortality in suckling piglets and severe gastroenteritis in young piglets (Antas and Woźniakowski, 2019). PED-CoV presents a similar clinical picture with TGE-CoV and PD-CoV (Chen et al., 2019). In addition, coinfection can occur (Marthaler et al., 2014).

\subsubsection{Transmissible swine gastroenteritis or TGE}

TGE-COV, which causes porcine transmissible gastroenteritis, was identified in the United States in 1945 (Doyle and Hutchings, 1946). Subsequently, the disease has been reported in many countries in Europe, Asia, Latin America and Africa (Cubero et al., 1993; Falsey et al., 1997; Hou et al., 2012; Martins et al., 2013; McIntosh, 1974; Pyrc et al., 2010; Williams et al., 1994). TGE manifests as an epidemic of watery diarrhea with vomiting, rapidly spreading affecting virtually all pigs in contact within days (Aynaud et al., 1985; Haelterman and Hooper, 1967). This enteropathogenic TGE-CoV, affects pigs of all ages (Martins et al., 2013).

\subsubsection{Porcine Respiratory CoV or PR-CoV}

$P R$-CoV was first identified in Belgium in 1984 (Usami et al., 2008)and subsequently in several countries including China, Japan, Uganda, and the United States (Laude et al., 1993; Muley, 2012; Wang et al., 2014). This CoV has a close antigenic relationship with enteropathogenic PEG-CoV (Rasschaert et al., 1990).

$P R$-CoV, derived from TGE-CoV by deletion of part of the $S$ gene, has lost its tropism for enterocytes and increased its tropism for the respiratory tract. It can cause mild respiratory disease in pigs, although most infections are subclinical (Chen et al., 2019). These two CoVs are cross-reactive, but serological tests are available to distinguish between them (Chen et al., 2019).

\subsubsection{Porcine Deltacoronavirus or PD}

Initially, PD-CoV was detected in 2009 in porcine fecal samples in Asia and then pigs in Hong Kong in 2012 (Woo et al., 2012). This CoV was not identified until 2014, when it caused diarrhea in pigs in the United States (Lee, 2015; Woo et al., 2012; Zhang, 2016; Zhou et al., 2018). Of unknown origin, genomic analyses suspect that PD-CoV may originate from an ancestral avian DeltaCoV (DCoV) (Woo et al., 2012). PD-CoV has caused diarrhea and intestinal lesions in infected piglets (Jung et al., 2015; VitoshSillman et al., 2016). PD-CoV continues to circulate and cause disease in swine herds worldwide (Boley et al., 2020).

\subsubsection{Swine Acute Diarrhea Syndrome or SADS}

In 2017, a fatal piglet diarrhea occurred in Guangdong Province, China (Zhou et al., 2019). This is Swine Acute Diarrhea Syndrome due to Swine Acute Diarrhea Syndrome-CoV or SADS-CoV (Gong et al., 2017; Pan et al., 2017). SADS-CoV is related to HKU2 virus found in bats of the genus Rhinolophus which is 
also shown to be the source of SARS-CoV from 2002-2003 (Cui et al., 2019). Since then, the disease has been controlled by immunizing sows from the intestines of infected piglets, but re-emerged on a pig farm two years later (Zhou et al., 2019). Apart from diarrhea, the disease also causes vomiting and weight loss in piglets which results in considerable economic loss in pig industry (Gong et al., 2017; Pan et al., 2017; Zhou et al., 2018). The mortality rate reaches 90\% (Zhou et al., 2018).

\subsubsection{Diarrhea, dysentery and respiratory infections in cattle}

Bovine CoV or BCoV causes three different diseases in cattle, as well as goats and sheep: calf diarrhea, winter dysentery, and respiratory infections such as bovine respiratory disease complex known as "shipping fever" in fattening (Balasuriya et al., 2017; Caswell and Williams, 2016; Peek et al., 2018; Underwood et al., 2015)and dairy producing animals (Perlman and Netland, 2009). The virus causes heavy economic impact in beef industry (Balasuriya et al., 2017). The form and severity of BCoV disease is related to season, age of animals, and secondary infections (Balasuriya et al., 2017).

In calves, BCoV diarrhea is often associated with other pathogens, Rotavirus and Cryptosporidium. A severe form is observed in case of co-infection with Bovine Viral Diarrhea Virus (BVDV), a Pestivirus of the family Flaviviridae (Uzal et al., 2016).

In winter, dysentery occurs in adult animals with a sporadic pattern (Balasuriya et al., 2017). Signs appear 20-36 hours after infection (Underwood et al., 2015).

In addition to the two digestive diseases, $B C o V$ also causes mild respiratory signs such as cough and rhinitis or severe signs such as pneumonia in calves 2-6 months of age (Balasuriya et al., 2017). Healthy or diseased carrier cattle then excrete BCoV either through the respiratory or digestive tract (Balasuriya et al., 2017).

\subsubsection{Feline CoV Complex}

Feline CoV or FCoV causes a mild or asymptomatic infection in domestic cats (Myrrha et al., 2011). But, persistent infection can cause the virus to mutate into a highly virulent strain called Feline Infectious Peritonitis CoV or FIP-CoV. This virulent strain, FIP-CoV is the cause of feline infectious peritonitis. FIP was discovered in 1963 in the United States (Holzworth, 1963)but FCoV was discovered only a few years later (Ward, 1970). Based on their variability, antigenicity, and in vitro growth pattern, FCoV can be divided into two serotypes: FCoV types-I and II (Fiscus and Teramoto, 1987; Shiba et al., 2007). The FCoV type-II variant is the result of heterologous recombination between the canine CoV variant CCoV type II and the feline FCoV type-I variant (Buonavoglia et al., 2006).

\subsubsection{Canine CoV Complex}

The first canine CoV or CCoV infection was reported in 1971 (Binn et al., 1974). Through molecular biology and pathobiology, much has been learned about CCoV. Like FCoV, CCoV is subdivided into two serotypes: CCoV type-I and CCoV type-II (Pratelli, 2006). CCoV type-I is genetically more similar to FCoV 
type-I than to CCoV type-II (Pratelli et al., 2003). Indeed, they evolved from a common ancestral virus (Licitra et al., 2014). CCoV type I infection in dogs is restricted to the enteric tract (Buonavoglia et al., 2006)and produces only mild or asymptomatic forms (Tennant et al., 1991). Whereas CCoV type-Il is a pantropic variant that is highly pathogenic to dogs (Buonavoglia et al., 2006).

\subsection{CoV diseases in humans}

After the discovery of the first strain of human $\mathrm{CoV}$ or HCoV, epidemiological studies have shown that $\mathrm{CoV}$ are generally associated with mild respiratory infections. HCoV-associated pathologies were not considered sufficiently moderate and did not arouse a clear interest in researchers. Thus, complete genomic studies of HCoV were not performed until 2003, following the identification of SARS-CoV, the infectious agent responsible for Severe Acute Respiratory Syndrome in China. Since then, three fatal HCoV outbreaks have been reported in 2002, 2012, and recently in 2019 (Figure 4). The severity of the infections varies from outbreak to outbreak although their clinical features are similar to themselves and other respiratory infections, making diagnosis difficult (Wang et al., 2020b).

\subsubsection{Cold flu}

CoVs are among the infectious agents that cause the common cold in humans during the winter months (Birch et al., 2005; Davis et al., 2018; Falsey et al., 2002; Tyrrell and Bynoe, 1965; van der Hoek et al., 2004). The first two strains of HCoV (HCoV-229E and HCoV-OC43) were isolated in 1962 and 1967, respectively (Bradburne et al., 1967; Hamre and Procknow, 1966; McIntosh et al., 1967; Woo et al., 2005). After the SARS event in China, two other HCoV strains (HCoV-NL63 in 2004 and HCoV-HKU1 in 2008) were isolated from patients with bronchiolitis and viral pneumonia (Cui et al., 2011; Lau et al., 2006; van der Hoek et al., 2004; Woo et al., 2005).

These four HCoVs are endemic and cause 15-30\% of upper respiratory tract infections each year (Fehr and Perlman, 2015; Jonsdottir and Dijkman, 2016; Larson et al., 1980). In addition, these HCoVs are adapted, spread and co-circulated in the human population (Kim et al., 2016).

\subsubsection{Severe Acute Respiratory Syndrome (SARS-2002)}

In 2002-2003, severe acute respiratory syndrome (SARS) emerged in Guangdong Province, China (Fields et al., 2013; Zhong et al., 2003). The disease clinically manifests as fever, headache, rhinorrhea, dry cough, difficulty breathing (Burrell et al., 2017; Cherry, 2004)and can progress to fatal pneumonia (Cherry, 2004). SARS-CoV infection has resulted in 8,096 cases and 774 deaths (Cherry, 2004) with 66\% of cases in China and has spread to 36 countries (Cherry, 2004; Swerdlow and Finelli, 2020). The overall mortality rate is $9.6-15 \%$ while the reproduction rate is greater than 2 (Swerdlow and Finelli, 2020). SARS-CoV is considered extinct within two years of its occurrence (Bleibtreu et al., 2019). 


\subsubsection{Middle East Respiratory Syndrome (MERS)}

In June 2012, a new respiratory syndrome was detected in Saudi Arabia (Bleibtreu et al., 2019; Burrell et al., 2017). The outbreak spread to 27 other countries (Bleibtreu et al., 2019; Burrell et al., 2017). After incubation, the most common symptoms are influenza-like illness (Mohd et al., 2016). The disease can be accompanied by acute respiratory distress syndrome, severe pneumonia, and multiple organ dysfunction resulting in death of the patient (Arabi et al., 2014; Garbati et al., 2016; Joob and Wiwanitkit, 2016; Mohd et al., 2016). To date, the majority of cases have been reported from Saudi Arabia (Bleibtreu et al., 2019).

\subsubsection{Wuhan pneumonia or COVID-19}

In late 2019, a new, unknown human CoV was identified in the city of Wuhan, China (Chan et al., 2020; Wang et al., 2020b; Wu et al., 2020b). In 2018, WHO already predicted a future deadly respiratory "disease X" (Honigsbaum, 2019). This disease is the third human CoV epidemic called COVID-19 or CoV Disease 2019 whose causative agent is SARS-CoV2 (Lai et al., 2020), formerly known as 2019-nCov (Paraskevis et al., 2020; Tang et al., 2020a; Wang et al., 2020a). Since its discovery, the number of reported cases of COVID -19 has been steadily increasing in several countries and WHO has classified it as an epidemic and then a pandemic of COVID -19 (World Health Organization, 2020).

\section{ORIGIN AND EVOLUTION OF COV}

\subsection{Evolution and plasticity of CoV}

The significant plasticity of their genome makes CoVs agents with high evolutionary potential (Karamitros et al., 2020). The two major modes of CoV evolution are mutations and recombination (Wu et al., 2020a). Indeed, recombination was concluded by Forni's team in 2017 to explain the origin of ORF8 of SARS-CoV, which has high sequence identity with that of civet CoV (Forni et al., 2017). The acquisition of an ORF8 (accessory protein) closely related to that of civet/human SARS-CoV was the results of recombination between CoVs within SARSr-Rs-CoV (Rs: Rhinolophus sinicus) or between SARSr-Rs-CoV and SARSr-Rf-CoV (Rf: Rhinolophus ferrumequinum) from bats (Lau et al., 2015b; Wu et al., 2016).

In CoV, despite the presence of nsp14 proofreading function (Ma et al., 2015), the replication complex generates many variants (Becares et al., 2016; Snijder et al., 2003). As with all RNA viruses, CoV is heterogeneous and has a quasi-species distribution (Mandary et al., 2019). This distribution can be seen as an optimization strategy to cope with environmental changes (Vignuzzi et al., 2006). It has been described for several CoVs not only in persistent infections, but also in acute infections (Lin et al., 2020; Mandary et al., 2019; Tang et al., 2020b). 
In bats, various CoVs are zoonotic potentials. Indeed, there are many opportunities for these zoonotic CoVs to evolve and recombine, leading to the emergence of new CoVs that are in the future more transmissible and/or lethal, in domestic animals as well as in humans (Ye et al., 2020).

\subsection{Reservoirs of COV}

Birds and bats are the primary reservoirs of CoV (Woo et al., 2012). Due to their clustering behavior and ability to fly long distances (Chan et al., 2013; de Sales Lima et al., 2015), they have the potential to spread emerging viruses among themselves and to other animal species and humans (Woo et al., 2012). Indeed, the flight adaptation of bats and birds promotes a rise in their body temperature allowing for an increased efficiency of the immune response (O'Shea et al., 2014; Rodhain, 2015; Zhang et al., 2013).

Bats harbor a diversity of CoVs including the ancestors of AlphaCoV and BetaCoV (Vijaykrishna et al., 2007), while the CoVs of birds are the ancestors of GammaCoV and DeltaCoV (Figure 5).

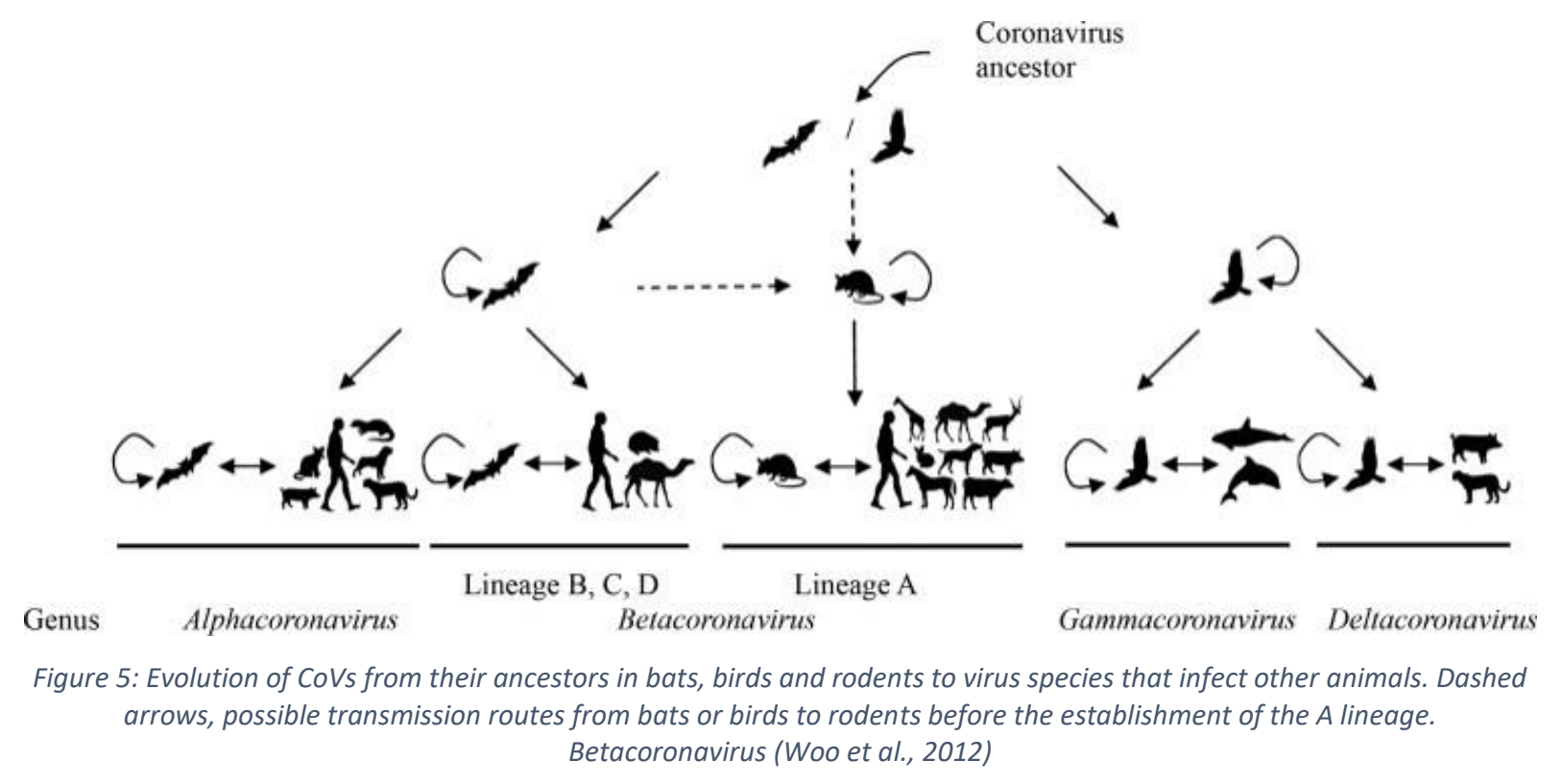

\subsection{Origin of the CoV}

Phylogenetic dating on RNA-dependent RNA polymerase divergence ( $n s p 12: R d R p)$ suggests that the time of the most recent common ancestor or tMRCA (Time of Most Recent Common Ancestor) of mammalian AlphaCoV, BetaCoV and avian GammCoV appeared around 7,000-8,000 BP or Before Present (Figure 6). That of GammaCoV and BetaCoV with DeltaCoV goes back another 2,000 years earlier to around -10,000 BP (Chan et al., 2013). These dates coincide with the onset of various human agricultural activities during the Neolithic Revolution (Figure-7) such as forest clearing for agriculture and domestication of wild animals (Borrell et al., 2015; Richards, 2002). These activities have led to a significant change in the ecology and population dynamics of CoV, due to the intrusion of wildlife habitat and the intensified mixing of wild or domestic animals, as primary, secondary, or tertiary hosts 
(Chan et al., 2013; Jones et al., 2013). Clearly, these human activities increase the potential for transmission of infections between bats, either with domesticated animals or with humans, via these intermediate hosts (Woo et al., 2012).

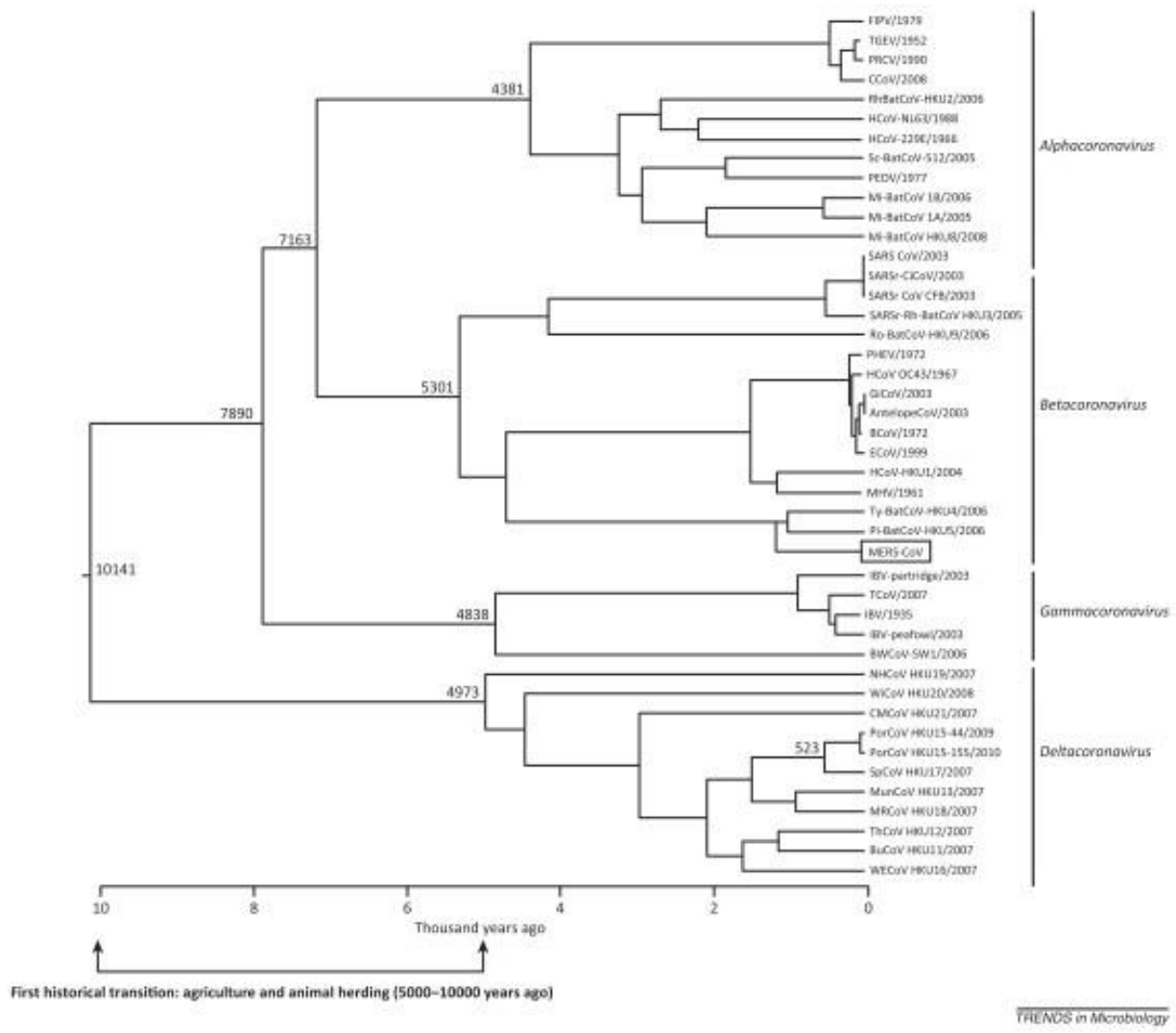

Figure 6: Molecular dating estimating the divergence of the genera AlphaCoV, BetaCoV, GammaCoV and DeltaCoV. This tree was generated by analyzing the RNA-dependent RNA polymerase (RdRp) genes under the relaxed clock model with an uncorrelated logarithmic normal with BEAST software. The values at the branch points represent the estimated time divergence in number of years to the present according to Woo's team (Woo et al., 2009).

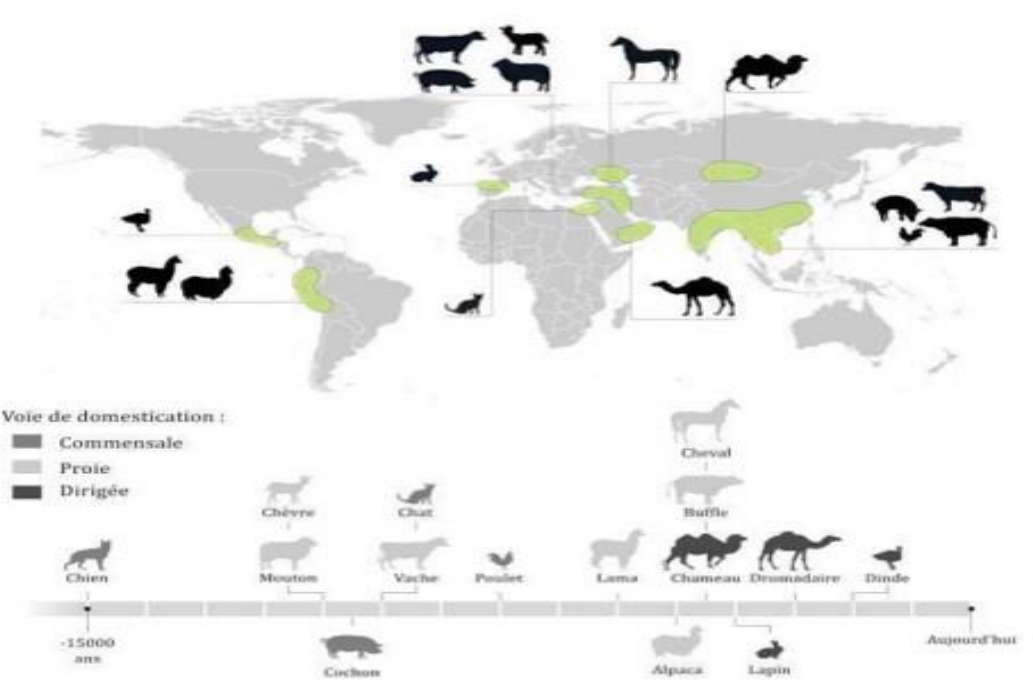

Figure 7: Neolithic Revolution - locations and dates of domestication of major domestic animals (Larson and Fuller, 2014) 
For years prior to the SARS outbreak in 2003, CoVs have been identified to cause various diseases in companion and production animals, often requiring vaccination (Gerdts and Zakhartchouk, 2017; Takamura et al., 2002). For the case of viruses causing infectious bronchitis (IBV - GammaCoV) in chickens, tMRCA with Alpha and BetaCoV has been traced back to around 8,000 BP (Figure-xx). IBV was first described in 1937 (Cook et al., 2012) phylogenetically very similar strains have been found in several wild bird species (de Sales Lima et al., 2015; Hughes et al., 2009). In Madagascar, 28\% (Lac Alaotra - $\mathrm{n}=357$ ) of individuals tested (17 wild bird species) tested positive for GammaCoV and the species Foudia madagascariensis, with a rate of $27 \%(n=11)$, was the most prevalent (de Sales Lima et al., 2015). The presence of different GammaCoV species in several healthy wild bird species (de Sales Lima et al., 2015; Liu et al., 2005; Sun et al., 2007), demonstrated the circulation and adaptation as well as evolution of GammaCoV in poultry (Hughes et al., 2009). In other words, the presumed intermediate hosts of this avian IBV CoV are wild birds (Mohammed et al., 2019). Since then, this avian disease has resulted in highly contagious and deadly acute respiratory epizootics worldwide (Cavanagh, 2007). Like other CoVs and Riboviruses, GammaCoVs are characterized by high genetic diversity induced by mutation and recombination (McKinley et al., 2011; Moreno et al., 2017). In addition, the massive vaccination campaign has generated positive selection at the spike or $\mathrm{S}$ glycoprotein level of circulating IBV strains (Franzo et al., 2019; McKinley et al., 2008). These characteristics can lead to the emergence of new GammaCoV and new lethal epizootics in avian species at any time (Woo et al., 2009).

In humans, intermediate hosts, such as cattle (Bovidae: Bos sp), alpaca (Camelidae: Vicugna pacos), dromedary (Camelidae: Camelus dromedarius), rodents (Rattus sp), and palm civet (Viviveridae: Paradoxurus hermaphroditus), have been cited as the origin of viruses, HCoV-OC43 (Hayman et al., 2013), HCoV-229E (Pfefferle et al., 2009), MERS-CoV (Zaki et al., 2012), HCoV-HKU1 (Lau et al., 2015a)and SARS-CoV1 (Drosten et al., 2003).

Indeed, the HCoVs responsible for the winter cold (-229E, -OC43, -NL63, and -HKU1) are currently welladapted after hundreds or thousands of years of circulation in the human population. Their evolutionary histories and associations with its hosts provide important information about the history of winter cold epidemics (Corman et al., 2018; Kim et al., 2016). The probable tMRCAs of these four winter cold-causing HCoVs are found in the years $1,200-1,500 ; 1,800 ; 1,900$ and 1,950 respectively (Forni et al., 2017; Lau et al., 2015a; Pfefferle et al., 2009). These dates coincided respectively with European discoveries of new lands such as America in the year 1500 (Darling and Donoghue, 2014; Marr and Cathey, 2010), the industrial revolution and new means of transportation such as steamboats leading to the dispersal of rats in the year 1800 (Brygoo, 1966), as well as the intensification of agriculture especially poultry, pig and cattle farming in the year 1900 (Jones et al., 2013; Rogalski et al., 2017). 
For COVID-19, the molecular divergence study between SARS-CoV2 and other related bat SARS CoVs (SARSr-CoV; RaTG13) showed 4\% genomic nucleotide variability. The novel functional site variations in the receptor binding domain (RBD) observed in SARS-CoV2 and pangolin SARS-CoVs are likely caused by mutations and natural selection in addition to recombination.

\subsection{Source of zoonotic diseases and species barrier}

Currently, based on molecular analyses, bats are the main reservoir of different strains of SARS-CoV (2002) and MERS-CoV (2012), SARS-CoV2 in 2019 (Wu et al., 2020b). These CoVs have crossed the species barrier and enzootically infect their intermediate hosts palm civet (Paguma larvata) and Dromedary or Camelus dromedarius respectively (Wit et al., 2016). While for SARS-CoV and MERS-CoV the intermediate hosts are known, questions still remain, whether SARS-CoV2 would be transmitted directly from bats to humans or indirectly via an intermediate host (Wu et al., 2020b; Zhou et al., 2020). A second time, these CoVs will cross the species barrier by infecting humans and have become zoonotic (Wit et al., 2016). The explosion of these three CoV into pandemics in humans is due to the fact that they are mainly spread by human-to-human transmission in society or nosocomial (Liu et al., 2020).

\section{Acknowledgements}

This study was supported by grants from FOFIFA-DRZVP team

\section{Authors Contributions}

Designed and conceived: M.O.F; Wrote the manuscript: M.O.F and R.M.S

\section{Competing Interests}

The authors declare that no competing interest exists. 


\section{REFERENCES}

Almeida J. D, Berry D.M., Cunningham C. H., Hamre D., Hofstad M. S., Mallucci L., McIntosh K., Tyrrell D.A. J., 1968. Virology: Coronaviruses. Nature 220: Novembre 16, 650.

Antas, M., Woźniakowski, G., 2019. Current Status of Porcine Epidemic Diarrhoea (PED) in European Pigs. J Vet Res 63, 465-470.

Arabi, Y.M., Arifi, A.A., Balkhy, H.H., Najm, H., Aldawood, A.S., Ghabashi, A., Hawa, H., Alothman, A., Khaldi, A., Al Raiy, B., 2014. Clinical course and outcomes of critically ill patients with Middle East respiratory syndrome coronavirus infection. Annals of internal medicine 160, 389-397.

Ashour, H.M., Elkhatib, W.F., Rahman, M.M., Elshabrawy, H.A., 2020. Insights into the Recent 2019 Novel Coronavirus (SARS-CoV-2) in Light of Past Human Coronavirus Outbreaks. Pathogens 9.

Aynaud, J.-M., Nguyen, T.D., Bottreau, E., Brun, A., Vannier, P., 1985. Transmissible Gastroenteritis (TGE) of Swine: Survivor Selection of TGE Virus Mutants in Stomach Juice of Adult Pigs. Journal of General Virology 66, 1911-1917.

Bailey, O.T., Pappenheimer, A.M., Cheever, F.S., Daniels, J.B., 1949. A murine virus (JHM) causing disseminated encephalomyelitis with extensive destruction of myelin : II. Pathology. J Exp Med 90, 195212.

Balasuriya, U.B.R., Barratt-Boyes, S., Beer, M., Bird, B., Brownlie, J., Coffey, L.L., Cullen, J.M., Delhon, G.A., Donis, R.O., Gardner, I., Gilkerson, J., Golde, W.T., Hartley, C., Heidner, H., Herden, C., Kirkland, P., Knowles, D.P., Meng, X.-J., Munday, J., Murphy, B., Niewiesk, S., Oglesbee, M., Osterrieder, K., Oura, C., Palmarini, M., Parker, J., Parrish, C.R., Pesavento, P., Reisen, W., Richt, J.A., Sigurdson, C.J., Towner, J., von Messling, V., Whittaker, G., 2017. Chapter 24 - Coronaviridae, In: Fenner's Veterinary Virology (Fifth Edition). Academic Press, Boston, pp. xvii-xviii.

Bande, F., Arshad, S.S., Omar, A.R., Bejo, M.H., Abubakar, M.S., Abba, Y., 2016. Pathogenesis and Diagnostic Approaches of Avian Infectious Bronchitis. Adv Virol 2016, 4621659.

Beaudette, F.R., Hudson, C.B., 1937. Cultivation of the virus of infectious bronchitis. J. Am. Vet. Med. Assoc . 90:, 51-58.

Becares, M., Pascual-Iglesias, A., Nogales, A., Sola, I., Enjuanes, L., Zuñiga, S., 2016. Mutagenesis of Coronavirus nsp14 Reveals Its Potential Role in Modulation of the Innate Immune Response. Journal of virology 90, 5399-5414.

Binn, L.N., Lazar, E.C., Keenan, K.P., Huxsoll, D.L., Marchwicki, R.H., Strano, A.J., 1974. Recovery and characterization of a coronavirus from military dogs with diarrhea. Proc Annu Meet U S Anim Health Assoc 78, 359-366.

Birch, C.J., Clothier, H.J., Seccull, A., Tran, T., Catton, M.C., Lambert, S.B., Druce, J.D., 2005. Human coronavirus OC43 causes influenza-like illness in residents and staff of aged-care facilities in Melbourne, Australia. Epidemiol Infect 133, 273-277.

Bleibtreu, A., Bertine, M., Bertin, C., Houhou-Fidouh, N., Visseaux, B., 2019. Focus on Middle East respiratory syndrome coronavirus (MERS-CoV). Médecine et Maladies Infectieuses.

Boley, P.A., Alhamo, M.A., Lossie, G., Yadav, K.K., Vasquez-Lee, M., Saif, L.J., Kenney, S.P., 2020. Porcine Deltacoronavirus Infection and Transmission in Poultry, United States(1). Emerg Infect Dis 26, 255-265. Borrell, F., Junno, A., Barceló, J.A., 2015. Synchronous Environmental and Cultural Change in the Emergence of Agricultural Economies 10,000 Years Ago in the Levant. PLOS ONE 10, e0134810.

Bradburne, A.F., 1970. Antigenic relationships amongst coronaviruses. Arch Gesamte Virusforsch 31, 352-364.

Bradburne, A.F., Bynoe, M.L., Tyrrell, D.A., 1967. Effects of a "new" human respiratory virus in volunteers. Br Med J 3, 767-769.

Brnić, D., Šimić, I., Lojkić, I., Krešić, N., Jungić, A., Balić, D., Lolić, M., Knežević, D., Hengl, B., 2019. The emergence of porcine epidemic diarrhoea in Croatia: molecular characterization and serology. BMC Vet Res 15, 249-249.

Brygoo, E.R., 1966. Epidemiologie de la peste à Madagascar. Arch Inst Pasteur Madagascar 35, 9-147. 
Buonavoglia, C., Decaro, N., Martella, V., Elia, G., Campolo, M., Desario, C., Castagnaro, M., Tempesta, M., 2006. Canine coronavirus highly pathogenic for dogs. Emerg Infect Dis 12, 492-494.

Burrell, C.J., Howard, C.R., Murphy, F.A., 2017. Chapter 31 - Coronaviruses, In: Fenner and White's Medical Virology (Fifth Edition). Academic Press, London, pp. 437-446.

Caswell, J.L., Williams, K.J., 2016. Chapter 5 - Respiratory System, In: Jubb, Kennedy \& Palmer's Pathology of Domestic Animals: Volume 2 (Sixth Edition). W.B. Saunders, pp. 465-591.e464.

Cavanagh, D., 2007. Coronavirus avian infectious bronchitis virus. Vet Res 38, 281-297.

Cavanagh, D., Gelb, J., 2008. Infectious bronchitis, In: Diseases of Poultry 12th edn (pp. 117-135). Blackwell Publishing Professional, Ames, lowa, USA.

Chan, J.F.-W., Yuan, S., Kok, K.-H., To, K.K.-W., Chu, H., Yang, J., Xing, F., Liu, J., Yip, C.C.-Y., Poon, R.W.S., Tsoi, H.-W., Lo, S.K.-F., Chan, K.-H., Poon, V.K.-M., Chan, W.-M., Ip, J.D., Cai, J.-P., Cheng, V.C.-C., Chen, H., Hui, C.K.-M., Yuen, K.-Y., 2020. A familial cluster of pneumonia associated with the 2019 novel coronavirus indicating person-to-person transmission: a study of a family cluster. The Lancet 395, 514523.

Chan, J.F., To, K.K., Tse, H., Jin, D.Y., Yuen, K.Y., 2013. Interspecies transmission and emergence of novel viruses: lessons from bats and birds. Trends Microbiol 21, 544-555.

Chasey, D., Cartwright, S.F., 1978. Virus-like particles associated with porcine epidemic diarrhoea. Res Vet Sci 25, 255-256.

Chen, F., Knutson, T.P., Rossow, S., Saif, L.J., Marthaler, D.G., 2019. Decline of transmissible gastroenteritis virus and its complex evolutionary relationship with porcine respiratory coronavirus in the United States. Scientific reports 9, 3953-3953.

Cherry, J.D., 2004. The chronology of the 2002-2003 SARS mini pandemic. Paediatric Respiratory Reviews 5, 262-269.

Cook, J.K., Jackwood, M., Jones, R.C., 2012. The long view: 40 years of infectious bronchitis research. Avian Pathol 41, 239-250.

Corman, V.M., Muth, D., Niemeyer, D., Drosten, C., 2018. Chapter Eight - Hosts and Sources of Endemic Human Coronaviruses, In: Advances in Virus Research. Academic Press, pp. 163-188.

Cubero, M.J., Leon, L., Contreras, A., Astorga, R., Lanza, I., Garcia, A., 1993. Transmissible gastroenteritis in pigs in south east Spain: prevalence and factors associated with infection. Vet Rec 132, 238-241.

Cui, J., Li, F., Shi, Z.L., 2019. Origin and evolution of pathogenic coronaviruses. 17, 181-192.

Cui, L.-J., Zhang, C., Zhang, T., Lu, R.-J., Xie, Z.-D., Zhang, L.-L., Liu, C.-Y., Zhou, W.-M., Ruan, L., Ma, X.-J., Tan, W.-J., 2011. Human Coronaviruses HCoV-NL63 and HCoV-HKU1 in Hospitalized Children with Acute Respiratory Infections in Beijing, China. Adv Virol 2011, 129134-129134.

Darling, M.I., Donoghue, H.D., 2014. Insights from paleomicrobiology into the indigenous peoples of pre-colonial America - a review. Mem Inst Oswaldo Cruz 109, 131-139.

Davis, B.M., Foxman, B., Monto, A.S., Baric, R.S., Martin, E.T., Uzicanin, A., Rainey, J.J., Aiello, A.E., 2018. Human coronaviruses and other respiratory infections in young adults on a university campus: Prevalence, symptoms, and shedding. Influenza Other Respir Viruses 12, 582-590.

de Sales Lima, F.E., Gil, P., Pedrono, M., Minet, C., Kwiatek, O., Campos, F.S., Spilki, F.R., Roehe, P.M., Franco, A.C., Maminiaina, O.F., Albina, E., de Almeida, R.S., 2015. Diverse gammacoronaviruses detected in wild birds from Madagascar. European Journal of Wildlife Research 61, 635-639.

Dea, S., Roy, R.S., Elazhary, M.A., 1981. Calf coronavirus neonatal diarrhea. A literature review (author's transl). Can Vet J 22, 51-58.

Doyle, L.P., Hutchings, L.M., 1946. A transmissible gastroenteritis in pigs. J Am Vet Med Assoc 108, 257259.

Drosten, C., Gunther, S., Preiser, W., van der Werf, S., Brodt, H.R., Becker, S., Rabenau, H., Panning, M., Kolesnikova, L., Fouchier, R.A., Berger, A., Burguiere, A.M., Cinatl, J., Eickmann, M., Escriou, N., Grywna, K., Kramme, S., Manuguerra, J.C., Muller, S., Rickerts, V., Sturmer, M., Vieth, S., Klenk, H.D., Osterhaus, A.D., Schmitz, H., Doerr, H.W., 2003. Identification of a novel coronavirus in patients with severe acute respiratory syndrome. N Engl J Med 348, 1967-1976. 
Falsey, A.R., McCann, R.M., Hall, W.J., Criddle, M.M., Formica, M.A., Wycoff, D., Kolassa, J.E., 1997. The "common cold" in frail older persons: impact of rhinovirus and coronavirus in a senior daycare center. J Am Geriatr Soc 45, 706-711.

Falsey, A.R., Walsh, E.E., Hayden, F.G., 2002. Rhinovirus and Coronavirus Infection-Associated Hospitalizations among Older Adults. The Journal of Infectious Diseases 185, 1338-1341.

Fehr, A.R., Perlman, S., 2015. Coronaviruses: an overview of their replication and pathogenesis. Methods Mol Biol 1282, 1-23.

Fields, B.N., Knipe, D.M., Howley, P.M., 2013. Fields virology. Wolters Kluwer Health/Lippincott Williams \& Wilkins, Philadelphia.

Fiscus, S.A., Teramoto, Y.A., 1987. Antigenic comparison of feline coronavirus isolates: evidence for markedly different peplomer glycoproteins. Journal of virology 61, 2607-2613.

Forni, D., Cagliani, R., Clerici, M., Sironi, M., 2017. Molecular Evolution of Human Coronavirus Genomes. Trends in microbiology 25, 35-48.

Franzo, G., Legnardi, M., Tucciarone, C.M., Drigo, M., Martini, M., Cecchinato, M., 2019. Evolution of infectious bronchitis virus in the field after homologous vaccination introduction. Veterinary Research 50, 92.

Garbati, M.A., Fagbo, S.F., Fang, V.J., Skakni, L., Joseph, M., Wani, T.A., Cowling, B.J., Peiris, M., Hakawi, A., 2016. A Comparative Study of Clinical Presentation and Risk Factors for Adverse Outcome in Patients Hospitalised with Acute Respiratory Disease Due to MERS Coronavirus or Other Causes. PLOS ONE 11, e0165978.

Gerdts, V., Zakhartchouk, A., 2017. Vaccines for porcine epidemic diarrhea virus and other swine coronaviruses. Veterinary microbiology 206, 45-51.

Gong, L., Li, J., Zhou, Q., Xu, Z., Chen, L., Zhang, Y., Xue, C., Wen, Z., Cao, Y., 2017. A New Bat-HKU2-like Coronavirus in Swine, China, 2017. Emerg Infect Dis 23.

Haelterman, E.O., Hooper, B.E., 1967. Transmissible gastroenteritis of swine as a model for the study of enteric disease. Gastroenterology 53, 109-113.

Hamre, D., Procknow, J.J., 1966. A new virus isolated from the human respiratory tract. Proc Soc Exp Biol Med 121, 190-193.

Hanke, D., Pohlmann, A., Sauter-Louis, C., Höper, D., Stadler, J., Ritzmann, M., Steinrigl, A., Schwarz, B.A., Akimkin, V., Fux, R., Blome, S., Beer, M., 2017. Porcine Epidemic Diarrhea in Europe: In-Detail Analyses of Disease Dynamics and Molecular Epidemiology. Viruses 9, 177.

Hayman, D.T.S., Bowen, R.A., Cryan, P.M., McCracken, G.F., O'Shea, T.J., Peel, A.J., Gilbert, A., Webb, C.T., Wood, J.L.N., 2013. Ecology of zoonotic infectious diseases in bats: current knowledge and future directions. Zoonoses Public Health 60, 2-21.

Herrewegh, A.A., Smeenk, I., Horzinek, M.C., Rottier, P.J., de Groot, R.J., 1998. Feline coronavirus type II strains 79-1683 and 79-1146 originate from a double recombination between feline coronavirus type I and canine coronavirus. Journal of virology $72,4508-4514$.

Holzworth, J., 1963. Some important disorders of cats. Cornell Vet 53, 157-160.

Honigsbaum, M., 2019. Disease $X$ and other unknowns. Lancet (London, England) 393, 1496-1497.

Hou, Y., Yue, X., Cai, X., Wang, S., Liu, Y., Yuan, C., Cui, L., Hua, X., Yang, Z., 2012. Complete genome of transmissible gastroenteritis virus AYU strain isolated in Shanghai, China. Journal of virology 86, 1193511935.

Hughes, L.A., Savage, C., Naylor, C., Bennett, M., Chantrey, J., Jones, R., 2009. Genetically diverse coronaviruses in wild bird populations of northern England. Emerg Infect Dis 15, 1091-1094.

Jafari A, Rezaei-Tavirani M, Karami S, Yazdani M, Zali H, Jafari Z, 2020. Cancer Care Management During the COVID-19 Pandemic. . Risk Manag Healthc Policy 13, 1711-1721 / https://doi.org/1710.2147/RMHP.S261357.

Jones, B.A., Grace, D., Kock, R., Alonso, S., Rushton, J., Said, M.Y., McKeever, D., Mutua, F., Young, J., McDermott, J., Pfeiffer, D.U., 2013. Zoonosis emergence linked to agricultural intensification and environmental change. Proceedings of the National Academy of Sciences of the United States of America 110, 8399-8404. 
Jonsdottir, H.R., Dijkman, R., 2016. Coronaviruses and the human airway: a universal system for virushost interaction studies. Virol J 13, 24-24.

Joob, B., Wiwanitkit, V., 2016. Middle East respiratory syndrome coronavirus infection: a short note on cases with renal failure problem. Renal failure 38, 1749-1750.

Jung, K., Hu, H., Eyerly, B., Lu, Z., Chepngeno, J., Saif, L.J., 2015. Pathogenicity of 2 porcine deltacoronavirus strains in gnotobiotic pigs. Emerg Infect Dis 21, 650-654.

Karamitros, T., Papadopoulou, G., Bousali, M., Mexias, A., Tsiodras, S., Mentis, A., 2020. SARS-CoV-2 exhibits intra-host genomic plasticity and low-frequency polymorphic quasispecies. bioRxiv, 2020.2003.2027.009480.

Kim, S., Thiessen, P.A., Bolton, E.E., Chen, J., Fu, G., Gindulyte, A., Han, L., He, J., He, S., Shoemaker, B.A., Wang, J., Yu, B., Zhang, J., Bryant, S.H., 2016. PubChem Substance and Compound databases. Nucleic Acids Res 44, D1202-D1213.

Lai, C.-C., Shih, T.-P., Ko, W.-C., Tang, H.-J., Hsueh, P.-R., 2020. Severe acute respiratory syndrome coronavirus 2 (SARS-CoV-2) and coronavirus disease-2019 (COVID-19): The epidemic and the challenges. International Journal of Antimicrobial Agents 55, 105924.

Larson, G., Fuller, D.Q., 2014. The Evolution of Animal Domestication. Annual Review of Ecology, Evolution, and Systematics 45, 115-136.

Larson, H.E., Reed, S.E., Tyrrell, D.A., 1980. Isolation of rhinoviruses and coronaviruses from 38 colds in adults. J Med Virol 5, 221-229.

Lau, S.K., Woo, P.C., Li, K.S., Tsang, A.K., Fan, R.Y., Luk, H.K., Cai, J.P., Chan, K.H., Zheng, B.J., Wang, M., Yuen, K.Y., 2015a. Discovery of a novel coronavirus, China Rattus coronavirus HKU24, from Norway rats supports the murine origin of Betacoronavirus 1 and has implications for the ancestor of Betacoronavirus lineage A. J Virol 89, 3076-3092.

Lau, S.K.P., Feng, Y., Chen, H., Luk, H.K.H., Yang, W.-H., Li, K.S.M., Zhang, Y.-Z., Huang, Y., Song, Z.-Z., Chow, W.-N., Fan, R.Y.Y., Ahmed, S.S., Yeung, H.C., Lam, C.S.F., Cai, J.-P., Wong, S.S.Y., Chan, J.F.W., Yuen, K.-Y., Zhang, H.-L., Woo, P.C.Y., 2015b. Severe Acute Respiratory Syndrome (SARS) Coronavirus ORF8 Protein Is Acquired from SARS-Related Coronavirus from Greater Horseshoe Bats through Recombination. Journal of virology 89, 10532-10547.

Lau, S.K.P., Woo, P.C.Y., Yip, C.C.Y., Tse, H., Tsoi, H.-W., Cheng, V.C.C., Lee, P., Tang, B.S.F., Cheung, C.H.Y., Lee, R.A., So, L.-y., Lau, Y.-I., Chan, K.-h., Yuen, K.-y., 2006. Coronavirus HKU1 and other coronavirus infections in Hong Kong. J Clin Microbiol 44, 2063-2071.

Laude, H., Van Reeth, K., Pensaert, M., 1993. Porcine respiratory coronavirus: molecular features and virus-host interactions. Vet Res 24, 125-150.

Lee, C., 2015. Porcine epidemic diarrhea virus: An emerging and re-emerging epizootic swine virus. Virol J 12, 193-193.

Licitra, B.N., Duhamel, G.E., Whittaker, G.R., 2014. Canine enteric coronaviruses: emerging viral pathogens with distinct recombinant spike proteins. Viruses 6, 3363-3376.

Lin, L., Lu, L., Cao, W., Li, T., 2020. Hypothesis for potential pathogenesis of SARS-CoV-2 infection-a review of immune changes in patients with viral pneumonia. Emerg Microbes Infect 9, 727-732.

Liu, J., Xie, W., Wang, Y., Xiong, Y., Chen, S., Han, J., Wu, Q., 2020. A comparative overview of COVID-19, MERS and SARS: Review article. International journal of surgery (London, England) 81, 1-8.

Liu, S., Chen, J., Chen, J., Kong, X., Shao, Y., Han, Z., Feng, L., Cai, X., Gu, S., Liu, M., 2005. Isolation of avian infectious bronchitis coronavirus from domestic peafowl (Pavo cristatus) and teal (Anas). Journal of General Virology 86, 719-725.

Ma, Y., Wu, L., Shaw, N., Gao, Y., Wang, J., Sun, Y., Lou, Z., Yan, L., Zhang, R., Rao, Z., 2015. Structural basis and functional analysis of the SARS coronavirus nsp14-nsp10 complex. Proc Natl Acad Sci U S A 112, 9436-9441.

Maminiaina OF, Razafindrafara MS, Randriamamisolonirina AT, Andriamaroarison TD, Razafinarivo TD, Andrianony SA, Ravelomanantsoa MA, Raberiaka TH, Zanamasy RC, Hevidrazana JL, Rasamoel PV, Koko, Rajaonarison JJ, Rakotonirina HHC., 2020. Connaissances Actuelles Sur Les Coronavirus Bulletin de l'Académie Malgache (en cours). 
Mandary, M.B., Masomian, M., Poh, C.L., 2019. Impact of RNA Virus Evolution on Quasispecies Formation and Virulence. Int J Mol Sci 20, 4657.

Marr, J.S., Cathey, J.T., 2010. New hypothesis for cause of epidemic among native Americans, New England, 1616-1619. Emerg Infect Dis 16, 281-286.

Marthaler, D., Raymond, L., Jiang, Y., Collins, J., Rossow, K., Rovira, A., 2014. Rapid detection, complete genome sequencing, and phylogenetic analysis of porcine deltacoronavirus. Emerg Infect Dis 20, 13471350.

Martins, A.M.C.R.P.F., Bersano, J.G., Ogata, R., Amante, G., Nastari, B.D.B., Catroxo, M.H.B., 2013. Diagnosis to Detect Porcine Transmissible Gastroenteritis Virus (TGEV) by Optical and Transmission Electron Microscopy Techniques. International Journal of Morphology 31, 706-715.

McIntosh, K., 1974. Coronaviruses: a comparative review. Curr. Top. Microbiol. Immunol. 63:, 85-129.

McIntosh, K., Becker, W.B., Chanock, R.M., 1967. Growth in suckling-mouse brain of "IBV-like" viruses from patients with upper respiratory tract disease. Proceedings of the National Academy of Sciences of the United States of America 58, 2268-2273.

McKinley, E.T., Hilt, D.A., Jackwood, M.W., 2008. Avian coronavirus infectious bronchitis attenuated live vaccines undergo selection of subpopulations and mutations following vaccination. Vaccine 26, 12741284.

McKinley, E.T., Jackwood, M.W., Hilt, D.A., Kissinger, J.C., Robertson, J.S., Lemke, C., Paterson, A.H., 2011. Attenuated live vaccine usage affects accurate measures of virus diversity and mutation rates in avian coronavirus infectious bronchitis virus. Virus Res 158, 225-234.

Mohammed, A.R., Rania, F.E., Ahmed, M.H., Mahmoud, M.B., Mohamed, A.E., Kawkab, A.A., Muhammad, Z.S., Muhammad, M., 2019. Genetic Diversity and Phylodynamics of Avian Coronaviruses in Egyptian Wild Birds. Viruses 11, 57.

Mohd, H.A., Memish, Z.A., Alfaraj, S.H., McClish, D., Altuwaijri, T., Alanazi, M.S., Aloqiel, S.A., Alenzi, A.M., Bafaqeeh, F., Mohamed, A.M., Aldosari, K., Ghazal, S., 2016. Predictors of MERS-CoV infection: A large case control study of patients presenting with ILI at a MERS-CoV referral hospital in Saudi Arabia. Travel medicine and infectious disease 14, 464-470.

Mora-Díaz, J.C., Piñeyro, P.E., Houston, E., Zimmerman, J., Giménez-Lirola, L.G., 2019. Porcine Hemagglutinating Encephalomyelitis Virus: A Review. Front Vet Sci 6, 53-53.

Moreno, A., Franzo, G., Massi, P., Tosi, G., Blanco, A., Antilles, N., Biarnes, M., Majo, N., Nofrarias, M., Dolz, R., Lelli, D., Sozzi, E., Lavazza, A., Cecchinato, M., 2017. A novel variant of the infectious bronchitis virus resulting from recombination events in Italy and Spain. Avian Pathol 46, 28-35.

Muley, T., 2012. The possible role of transmissible gastroenteritis virus (TGE) and porcine respiratory corona virus (PRCV) in the mortality of Ugandan back-yard piglets. . Swedish University of Agricultural Sciences.

Myrrha, L.W., Silva, F.M.F., Peternelli, E.F.d.O., Junior, A.S., Resende, M., de Almeida, M.R., 2011. The paradox of feline coronavirus pathogenesis: a review. Adv Virol 2011, 109849-109849.

O'Shea, T.J., Cryan, P.M., Cunningham, A.A., Fooks, A.R., Hayman, D.T.S., Luis, A.D., Peel, A.J., Plowright, R.K., Wood, J.L.N., 2014. Bat flight and zoonotic viruses. Emerg Infect Dis 20, 741-745.

Pan, Y., Tian, X., Qin, P., Wang, B., Zhao, P., Yang, Y.L., Wang, L., Wang, D., Song, Y., Zhang, X., Huang, Y.W., 2017. Discovery of a novel swine enteric alphacoronavirus (SeACoV) in southern China. Vet Microbiol 211, 15-21.

Paraskevis, D., Kostaki, E.G., Magiorkinis, G., Panayiotakopoulos, G., Sourvinos, G., Tsiodras, S., 2020. Full-genome evolutionary analysis of the novel corona virus (2019-nCoV) rejects the hypothesis of emergence as a result of a recent recombination event. Infection, Genetics and Evolution 79, 104212. Pauly, M., Snoeck, C.J., Phoutana, V., Keosengthong, A., Sausy, A., Khenkha, L., Nouanthong, P., Samountry, B., Jutavijittum, P., Vilivong, K., Hübschen, J.M., Black, A.P., Pommasichan, S., Muller, C.P., 2019. Cross-species transmission of poultry pathogens in backyard farms: ducks as carriers of chicken viruses. Avian Pathology 48, 503-511.

Peek, S.F., McGuirk, S.M., Sweeney, R.W., Cummings, K.J., 2018. 6 - Infectious Diseases of the Gastrointestinal Tract, In: Rebhun's Diseases of Dairy Cattle (Third Edition). Elsevier, pp. 249-356. 
Peiris, J.S.M., Guan, Y., Yuen, K.Y., 2004. Severe acute respiratory syndrome. Nature Medicine 10, S88S97.

Pensaert, M.B., de Bouck, P., 1978. A new coronavirus-like particle associated with diarrhea in swine. Arch Virol 58, 243-247.

Perlman, S., Netland, J., 2009. Coronaviruses post-SARS: update on replication and pathogenesis. Nature reviews. Microbiology 7, 439-450.

Pfefferle, S., Oppong, S., Drexler, J.F., Gloza-Rausch, F., Ipsen, A., Seebens, A., Müller, M.A., Annan, A., Vallo, P., Adu-Sarkodie, Y., Kruppa, T.F., Drosten, C., 2009. Distant relatives of severe acute respiratory syndrome coronavirus and close relatives of human coronavirus 229E in bats, Ghana. Emerg Infect Dis 15, 1377-1384.

Pratelli, A., Martella, V., Decaro, N., Tinelli, A., Camero, M., Cirone, F., Elia, G., Cavalli, A., Corrente, M., Greco, G., Buonavoglia, D., Gentile, M., Tempesta, M., Buonavoglia, C., 2003. Genetic diversity of a canine coronavirus detected in pups with diarrhoea in Italy. Journal of Virological Methods 110, 9-17.

Pratelli, P., 2006. Genetic evolution of canine coronavirus and recent advances in prophylaxis. Vet. Res. 37, 191-200.

Pyrc, K., Sims, A.C., Dijkman, R., Jebbink, M., Long, C., Deming, D., Donaldson, E., Vabret, A., Baric, R., van der Hoek, L., Pickles, R., 2010. Culturing the unculturable: human coronavirus HKU1 infects, replicates, and produces progeny virions in human ciliated airway epithelial cell cultures. J Virol 84, 11255-11263.

Rasschaert, D., Duarte, M., Laude, H., 1990. Porcine respiratory coronavirus differs from transmissible gastroenteritis virus by a few genomic deletions. Journal of General Virology 71, 2599-2607.

Richards, M.P., 2002. A brief review of the archaeological evidence for Palaeolithic and Neolithic subsistence. European Journal of Clinical Nutrition 56, 1270-1278.

Rodhain, F., 2015. Bats and Viruses: complex relationships. Bull Soc Pathol Exot 108, 272-289.

Roe, C.K., Alexander, T.J., 1958. A Disease of Nursing Pigs Previously Unreported in Ontario. Can J Comp Med Vet Sci 22, 305-307.

Rogalski, M.A., Gowler, C.D., Shaw, C.L., Hufbauer, R.A., Duffy, M.A., 2017. Human drivers of ecological and evolutionary dynamics in emerging and disappearing infectious disease systems. Philos Trans R Soc Lond B Biol Sci 372, 20160043.

Shah, V.K., Firmal, P., Alam, A., Ganguly, D., Chattopadhyay, S., 2020. Overview of Immune Response During SARS-CoV-2 Infection: Lessons From the Past. Front Immunol 11, 1949.

Shiba, N., Maeda, K., Kato, H., Mochizuki, M., Iwata, H., 2007. Differentiation of feline coronavirus type I and II infections by virus neutralization test. Veterinary Microbiology 124, 348-352.

Snijder, E.J., Bredenbeek, P.J., Dobbe, J.C., Thiel, V., Ziebuhr, J., Poon, L.L., Guan, Y., Rozanov, M., Spaan, W.J., Gorbalenya, A.E., 2003. Unique and conserved features of genome and proteome of SARScoronavirus, an early split-off from the coronavirus group 2 lineage. Journal of molecular biology 331, 991-1004.

Song, D., Moon, H., Kang, B., 2015. Porcine epidemic diarrhea: a review of current epidemiology and available vaccines. Clin Exp Vaccine Res 4, 166-176.

Sun, L., Zhang, G.-h., Jiang, J.-W., Fu, J.-d., Ren, T., Cao, W.-s., Xin, C.-a., Liao, M., Liu, W.-j., 2007. A Massachusetts prototype like coronavirus isolated from wild peafowls is pathogenic to chickens. Virus Research 130, 121-128.

Swerdlow, D.L., Finelli, L., 2020. Preparation for Possible Sustained Transmission of 2019 Novel Coronavirus: Lessons From Previous Epidemics. JAMA.

Takamura, K., Matsumoto, Y., Shimizu, Y., 2002. Field study of bovine coronavirus vaccine enriched with hemagglutinating antigen for winter dysentery in dairy cows. Can J Vet Res 66, 278-281.

Tang, B., Bragazzi, N.L., Li, Q., Tang, S., Xiao, Y., Wu, J., 2020a. An updated estimation of the risk of transmission of the novel coronavirus (2019-nCov). Infectious Disease Modelling 5, 248-255.

Tang, X., Wu, C., Li, X., Song, Y., Yao, X., Wu, X., Duan, Y., Zhang, H., Wang, Y., Qian, Z., Cui, J., Lu, J., 2020b. On the origin and continuing evolution of SARS-CoV-2. National Science Review.

Tennant, B.J., Gaskell, R.M., Kelly, D.F., Carter, S.D., Gaskell, C.J., 1991. Canine coronavirus infection in the dog following oronasal inoculation. Research in Veterinary Science 51, 11-18. 
Tobler, K., Ackermann, M., 1996. Identification and characterization of new and unknown coronaviruses using RT-PCR and degenerate primers. Schweiz Arch Tierheilkd 138, 80-86.

Tyrrell, D.A., Bynoe, M.L., 1965. Cultivation of a novel type of common-cold virus in organ cultures. $\mathrm{Br}$ Med J 1, 1467-1470.

Underwood, W.J., Blauwiekel, R., Delano, M.L., Gillesby, R., Mischler, S.A., Schoell, A., 2015. Chapter 15 - Biology and Diseases of Ruminants (Sheep, Goats, and Cattle), In: Laboratory Animal Medicine (Third Edition). Academic Press, Boston, pp. 623-694.

Usami, Y., Fukai, K., Ichikawa, Y., Okuda, Y., Shibata, I., Motoyama, C., Imai, K., Kirisawa, R., 2008. Virological and Serological Studies of Porcine Respiratory Coronavirus Infection on a Japanese Farm. Journal of Veterinary Medical Science 70, 929-936.

Uzal, F.A., Plattner, B.L., Hostetter, J.M., 2016. Chapter 1 - Alimentary System, In: Jubb, Kennedy \& Palmer's Pathology of Domestic Animals: Volume 2 (Sixth Edition). W.B. Saunders, pp. 1-257.e252.

V'kovski, P., Kratzel, A., Steiner, S., Stalder, H., Thiel, V., 2021. Coronavirus biology and replication: implications for SARS-CoV-2. Nature Reviews Microbiology 19, 155-170.

van der Hoek, L., Pyrc, K., Jebbink, M.F., Vermeulen-Oost, W., Berkhout, R.J., Wolthers, K.C., Wertheimvan Dillen, P.M., Kaandorp, J., Spaargaren, J., Berkhout, B., 2004. Identification of a new human coronavirus. Nat Med 10, 368-373.

Vignuzzi, M., Stone, J.K., Arnold, J.J., Cameron, C.E., Andino, R., 2006. Quasispecies diversity determines pathogenesis through cooperative interactions in a viral population. Nature 439, 344-348.

Vijaykrishna, D., Smith, G.J.D., Zhang, J.X., Peiris, J.S.M., Chen, H., Guan, Y., 2007. Evolutionary insights into the ecology of coronaviruses. Journal of virology 81, 4012-4020.

Vitosh-Sillman, S., Loy, J.D., Brodersen, B., Kelling, C., Doster, A., Topliff, C., Nelson, E., Bai, J., Schirtzinger, E., Poulsen, E., Meadors, B., Anderson, J., Hause, B., Anderson, G., Hesse, R., 2016. Experimental infection of conventional nursing pigs and their dams with Porcine deltacoronavirus. J Vet Diagn Invest 28, 486-497.

Wang, L., Byrum, B., Zhang, Y., 2014. Porcine coronavirus HKU15 detected in 9 US states, 2014. Emerg Infect Dis 20, 1594-1595.

Wang, M., Zhou, Y., Zong, Z., Liang, Z., Cao, Y., Tang, H., Song, B., Huang, Z., Kang, Y., Feng, P., Ying, B., Li, W., 2020a. A precision medicine approach to managing 2019 novel coronavirus pneumonia. Precision Clinical Medicine.

Wang, M., Zhou, Y., Zong, Z., Liang, Z., Cao, Y., Tang, H., Song, B., Huang, Z., Kang, Y., Feng, P., Ying, B., Li, W., 2020b. A precision medicine approach to managing Wuhan Coronavirus pneumonia. Precision Clinical Medicine.

Ward, J.M., 1970. Morphogenesis of a virus in cats with experimental feline infectious peritonitis. Virology 41, 191-194.

Williams, R., Esterhuysen, J.J., Robinson, J.T., 1994. Pseudorabies and transmissible gastroenteritis: a serological survey in South Africa. Onderstepoort J Vet Res 61, 67-70.

Wit, E.d., Doremalen, N.v., Falzarano, D., Munster, V., 2016. SARS and MERS: recent insights into emerging coronaviruses. Nature Reviews. Microbiology 14, 523 - 534.

Woo, P.C., Lau, S.K., Huang, Y., Yuen, K.Y., 2009. Coronavirus diversity, phylogeny and interspecies jumping. Exp Biol Med (Maywood) 234, 1117-1127.

Woo, P.C.Y., Lau, S.K.P., Chu, C.-m., Chan, K.-h., Tsoi, H.-W., Huang, Y., Wong, B.H.L., Poon, R.W.S., Cai, J.J., Luk, W.-k., Poon, L.L.M., Wong, S.S.Y., Guan, Y., Peiris, J.S.M., Yuen, K.-y., 2005. Characterization and complete genome sequence of a novel coronavirus, coronavirus HKU1, from patients with pneumonia. Journal of virology $79,884-895$.

Woo, P.C.Y., Lau, S.K.P., Lam, C.S.F., Lau, C.C.Y., Tsang, A.K.L., Lau, J.H.N., Bai, R., Teng, J.L.L., Tsang, C.C.C., Wang, M., Zheng, B.-J., Chan, K.-H., Yuen, K.-Y., 2012. Discovery of seven novel Mammalian and avian coronaviruses in the genus deltacoronavirus supports bat coronaviruses as the gene source of alphacoronavirus and betacoronavirus and avian coronaviruses as the gene source of gammacoronavirus and deltacoronavirus. Journal of virology 86, 3995-4008. 
World Health Organization, 2020. WHO Director-General's opening remarks at the media briefing on COVID-19 - 11 March 2020. https://www.who.int/dg/speeches/detail/who-director-general-s-openingremarks-at-the-media-briefing-on-covid-19---11-march-2020 (accessed 12 mars 2020.

Wu, A., Niu, P., Wang, L., Zhou, H., Zhao, X., Wang, W., Wang, J., Ji, C., Ding, X., Wang, X., Lu, R., Gold, S., Aliyari, S., Zhang, S., Vikram, E., Zou, A., Lenh, E., Chen, J., Ye, F., Han, N., Peng, Y., Guo, H., Wu, G., Jiang, T., Tan, W., Cheng, G., 2020a. Mutations, Recombination and Insertion in the Evolution of 2019nCoV. bioRxiv, 2020.2002.2029.971101.

Wu, D., Wu, T., Liu, Q., Yang, Z., 2020b. The SARS-CoV-2 outbreak: what we know. International Journal of Infectious Diseases.

Wu, Z., Yang, L., Ren, X., Zhang, J., Yang, F., Zhang, S., Jin, Q., 2016. ORF8-Related Genetic Evidence for Chinese Horseshoe Bats as the Source of Human Severe Acute Respiratory Syndrome Coronavirus. The Journal of infectious diseases 213, 579-583.

Ye, Z.-W., Yuan, S., Yuen, K.-S., Fung, S.-Y., Chan, C.-P., Jin, D.-Y., 2020. Zoonotic origins of human coronaviruses. International journal of biological sciences 16, 1686-1697.

Zaki, A.M., van Boheemen, S., Bestebroer, T.M., Osterhaus, A.D.M.E., Fouchier, R.A.M., 2012. Isolation of a Novel Coronavirus from a Man with Pneumonia in Saudi Arabia. New England Journal of Medicine 367, 1814-1820.

Zeng, Q., Langereis, M.A., van Vliet, A.L.W., Huizinga, E.G., de Groot, R.J., 2008. Structure of coronavirus hemagglutinin-esterase offers insight into corona and influenza virus evolution. Proceedings of the National Academy of Sciences of the United States of America 105, 9065-9069.

Zhang, G., Cowled, C., Shi, Z., Huang, Z., Bishop-Lilly, K.A., Fang, X., Wynne, J.W., Xiong, Z., Baker, M.L., Zhao, W., Tachedjian, M., Zhu, Y., Zhou, P., Jiang, X., Ng, J., Yang, L., Wu, L., Xiao, J., Feng, Y., Chen, Y., Sun, X., Zhang, Y., Marsh, G.A., Crameri, G., Broder, C.C., Frey, K.G., Wang, L.-F., Wang, J., 2013. Comparative Analysis of Bat Genomes Provides Insight into the Evolution of Flight and Immunity. Science $339,456$.

Zhang, J., 2016. Porcine deltacoronavirus: Overview of infection dynamics, diagnostic methods, prevalence and genetic evolution. Virus Research 226, 71-84.

Zhong, N.S., Zheng, B.J., Li, Y.M., Poon, Xie, Z.H., Chan, K.H., Li, P.H., Tan, S.Y., Chang, Q., Xie, J.P., Liu, X.Q., Xu, J., Li, D.X., Yuen, K.Y., Peiris, Guan, Y., 2003. Epidemiology and cause of severe acute respiratory syndrome (SARS) in Guangdong, People's Republic of China, in February, 2003. Lancet (London, England) 362, 1353-1358.

Zhou, L., Li, Q.N., Su, J.N., Chen, G.H., Wu, Z.X., Luo, Y., Wu, R.T., Sun, Y., Lan, T., Ma, J.Y., 2019. The reemerging of SADS-CoV infection in pig herds in Southern China. Transboundary and Emerging Diseases 66, 2180-2183.

Zhou, P., Fan, H., Lan, T., Yang, X.L., Shi, W.F., Zhang, W., Zhu, Y., Zhang, Y.W., Xie, Q.M., Mani, S., Zheng, X.S., Li, B., Li, J.M., Guo, H., Pei, G.Q., An, X.P., Chen, J.W., Zhou, L., Mai, K.J., Wu, Z.X., Li, D., Anderson, D.E., Zhang, L.B., Li, S.Y., Mi, Z.Q., He, T.T., Cong, F., Guo, P.J., Huang, R., Luo, Y., Liu, X.L., Chen, J., Huang, Y., Sun, Q., Zhang, X.L., Wang, Y.Y., Xing, S.Z., Chen, Y.S., Sun, Y., Li, J., Daszak, P., Wang, L.F., Shi, Z.L., Tong, Y.G., Ma, J.Y., 2018. Fatal swine acute diarrhoea syndrome caused by an HKU2-related coronavirus of bat origin. Nature 556, 255-258.

Zhou, P., Yang, X.L., Wang, X.G., Hu, B., Zhang, L., Zhang, W., Si, H.R., Zhu, Y., Li, B., Huang, C.L., Chen, H.D., Chen, J., Luo, Y., Guo, H., Jiang, R.D., Liu, M.Q., Chen, Y., Shen, X.R., Wang, X., Zheng, X.S., Zhao, K., Chen, Q.J., Deng, F., Liu, L.L., Yan, B., Zhan, F.X., Wang, Y.Y., Xiao, G.F., Shi, Z.L., 2020. A pneumonia outbreak associated with a new coronavirus of probable bat origin. Nature 579, 270-273. 